\title{
Kadar NaCl dan pH Lendir Serviks Rusa Timor (Rusa timorensis) Betina yang Mendapat Suplementasi Mineral selama Siklus Estrus
}

\author{
Levels $\mathrm{NaCl}$ and pH Mucous of Female Timor Deer (Deer timorensis) Getting Mineral \\ Supplementation during Estrous Cycle
}

\author{
A. Makmun, D. Samsudewa dan Y. S. Ondho \\ Fakultas Peternakan dan Pertanian Universitas Diponegoro, Semarang. \\ agusmbadman@gmail.com
}

\begin{abstract}
The aims of this research were to observe the effect of minerals on the $\mathrm{NaCl}$ content and $\mathrm{pH}$ (potential of Hydrogen) of cervical mucus. The benefits of this research were to provide information to the breeder that providing of mineral supplementation can increase the levels of $\mathrm{NaCl}$ content and $\mathrm{pH}$ of cervical mucus and the importance of mineral supplementation on female reproductive Timor deer. The materials used were 10 deers that had BCS (Body Condition Score) from 2,5- 3,25, Poel 2 having been calving and physically fit. The treatment given, mineral supplementation $(\mathrm{Mg}, \mathrm{Zn}$ and $\mathrm{Se})$ was in the form of mineral blocks (T1) and the control (T0) was for 8 weeks, then in sync sponge MPA was for 16 days. Cervical mucus sample taken at 0,24 , $72,84,96,108,120$ and 144 hours after the release of the sponge. The parameters observed $\mathrm{NaCl}$ content and $\mathrm{pH}$ of cervical mucus. Analysis of the data used is the SPSS statistical tests T-Test. The results showed that there was no significant difference $(\mathrm{P}>0.05)$ of supplementation of minerals $(\mathrm{Mg}, \mathrm{Zn}$ and $\mathrm{Se})$ on $\mathrm{NaCl}$ and $\mathrm{pH}$ on concentration cervical mucus of Timor deer females during the estrous cycle.
\end{abstract}

Key words: mineral supplementation, cervical mucus, Timor deer, $\mathrm{pH}, \mathrm{NaCl}$.

\begin{abstract}
ABSTRAK
Penelitian ini bertujuan untuk mengetahui pengaruh mineral terhadapkadar $\mathrm{NaCl}$ dan $\mathrm{pH}$ (potential of Hydrogen) lendir serviks. Manfaat dari penelitian adalah memberikan informasi kepada penanagkar untuk mengetahui tanda-tanda rusa birahi melalui profil $\mathrm{pH}$ dan kadar $\mathrm{NaCl}$ lendir serviks dan pentingnya suplementasi mineral terhadap reproduksi betina rusa Timor. Materi yang digunakan adalah 10 ekor rusa yang memiliki BCS (Body Condition Score) 2,5-3,25, poel 2 serta pernah melahirkan dan sehat secara fisik. Perlakuan yang diberikan berupa suplementasi mineral ( $\mathrm{Mg}, \mathrm{Zn}$ dan Se) dalam bentuk mineral blok (T1) dan kontrol (T0) selama 8 minggu, kemudian di sinkronisasi spon MPA selama 16 hari. Sampel lendir serviks diambil pada jam ke-0, 24, 72, 84, 96, 108, 120 dan 144 setelah pelepasan spon. Parameter yang diamati meliputi kadar $\mathrm{NaCl}$ danpH lendir serviks.Analisis data yang digunakan adalah statistik SPSS uji T-Test. Hasil penelitian menunjukan bahwa $(\mathrm{P}>0,05)$ tidak ada perbedaan nyata suplementasi mineral $(\mathrm{Mg}, \mathrm{Zn}$ dan $\mathrm{Se})$ terhadap kadar $\mathrm{NaCl}$ dan $\mathrm{pH}$ lendir serviks rusa Timor betina selama siklus estrus.
\end{abstract}

Kata kunci: suplementasi mineral, lendir serviks, Rusa Timor, $\mathrm{pH}, \mathrm{NaCl}$.

\section{PENDAHULUAN}

Rusa merupakan salah satu ternak yang dikembangkan sebagai satwa harapan yang mampu menyumbang produk daging untuk memenuhi kebutuhan protein hewani masyarakat, selain produk itu antara lain kulit dan velvet (ranggah muda). Potensi karkas daging rusa relatif lebih tinggi mencapai $60-70 \%$ dari bobot badan. Selain itu rusa dapat dipelihara penangkar menjadai breeding stock dan dapat dipelihara dengan tujuan komersial.

Secara reproduksi, rusa Timor betina mempunyai kendala yang dihadapi penangkar adalah pola perkembang biakan rusa yang bersifat tidak mempunyai musim kawin dan dapat birahi berulang kali sepanjang tahun. Permasalahan yang ada pada rusa Timor adalah adanya musim kawin sehingga perkawinan tidak dapat 
dilakukan setiap waktu (Samsudewa dan Susanti, 2006).

Penangkaranharus mangetahui manajemen reproduksi rusa yang ditangkarkan,yakni melalui penentu an waktu kawin yang tepat untuk meningkatkan efisiensi reproduksi. Kenyataanya, hal ini masih belum dicapai dikarenakan para penangkar belum mampu mengenali tanda-tanda birahi yang tampak pada rusa sebagai penentu waktu kawin. Salah satu tanda indikator birahi adalah lendir serviks.

Lendir serviks mempunyai sifatsifat reologi yang memberikan nilai kualitas untik menentukan keberhasilan pada proses pembuahan. Pengamatan mulai dari kadar $\mathrm{NaCl}$ dan $\mathrm{pH}$ lender serviks yang dapat di gunakan sebagai indikasi seekor ternak berada dalam siklus birahi. Lendir serviks adalah fenomena yang mengikuti adanya peningkatan sekresi estrogen. Lendir serviks dihasilkan oleh aktivitas biosintesis sel sekretorik di kanalis endoserviks dan dapat digunakan untuk mendeteksi adanya ovulasi. Lendir mulai meningkat beberapa saat setelah memasuki fase proestrus hingga akhirnya menyusut habis setelah hari ke-3 setelah estrus. Lendir serviks meningkat sejalan dengan peningkatan kadar estrogen diikuti dengan peningkatan kadar garam dalam lendir. Kandungan yang terdapat dalam lendir serviks diantaranya komponen air $(95-98,5 \%)$, protein $(1 \%), \mathrm{NaCl}(0,8 \%)$ dan musin (0,5-1,5\%). Lendir serviks mengandung garam-garam anorganik dengan kadar $1 \%$ dari komponen terlarut dan $\mathrm{NaCl}$ merupakan jenis garam yang terdapat paling banyak yaitu $0,7 \%$. Mineral-mineral lain dalam lendir serviks adalah $\mathrm{K}, \mathrm{Mg}, \mathrm{Ca}$, $\mathrm{Cu}$ dan $\mathrm{Zn}$ terdapat dalam bentuk trace element yang mempunyai fungsi penting dalah sejumlah enzim dan ribonukleat pada fase luteal dan dari semuanya $\mathrm{Na}$ terdapat dalam persentase terbesar (Mardiati, 2003).

Peningkatan estrogen dalam otak pada bagian hipotalamus akan meningkatkan ACTH dan corticosterone bassaly karena diinduksi oleh hormon luteinizing. Peningkatan $\mathrm{CRH}$ didalam hipotalmus akan merangsang pengeluaran adreno corticotropin (ACTH) di dalam hipofisa. Peningkatan ACTH didalam hipofisa akan merangsang pembentukan kortisol di dalam sel pada zona fasciculata. Zona gromerolusa dan zona fasciculate tidak berbeda jauh ketika terjadi peningkatan ACTH maka zona glomerolus kekurangan 17 a-hydroxylase dan akan mensintesis corticosterone dan di ubah menjadi aldosterone. Aldosteron didalam sel juxtaglomerular (JG) diubah menjadi angiostenin II (AII) melalui biosenti-tesis angiostenin. Biosintesis angiostenin dapat menyebabkan penyempitan didinding arteri dan menyebabkan tekanan darah meningkat. Ketika tekanan darah meningkat maka atrium jantung akan menyempit dan mengakibatkan volume darah di jantung berkurang. Berkurangnya volume darah dijantung dan terjadinya peningkatan tekanan darah menyebabkan terjadinya diuresis dan natriuresis. Korteks adrenal memiliki zona glomerulosa yang memproduksi hormon mineralokortikoid kemudian kerja utama hormon ini adalah untuk meningkatkan retensi $\mathrm{Na}^{+}$, ekskresi $\mathrm{K}^{+}$, serta $\mathrm{H}^{+}$, khususnya dalam ginjal dan 
akan meningkatkan pengeluaran didalam urin. Tujuan penelitian ini adalah memberikan informasi kepada penangkar pengaruh suplementasi mineral $(\mathrm{Mg}, \mathrm{Zn}$ dan Se) terhadap tanda-tanda birahi melalui kadar $\mathrm{NaCl}$ dan $\mathrm{pH}$ lender serviks selama siklus estrus dan terhadap reproduksi betina rusa Timor.

\section{MATERI DAN METODE}

Penelitian dilaksanakan pada tanggal 10 Maret sampai 30 Mei 2016 di Desa Margorejo, Kec. Dawe, Kab. Kudus. Materi penelitian ini menggunakan Rusa Timor yang memiliki BCS 2-3,25 dan poel 2 sebanyak 10 ekor. Rusa dalam kondisi yang sudah pernah melahirkan dan sehat fisik. Lendir serviks sebagai objek yang diamati. Perlakuan mineral yang digunakan adalah Magnesium (Mg), Zink (Zn) dan Selenium (Se) yang dibentuk mineral blok.

Metode penelitian ini dilakukan beberapa tahap yaitu analisis pakan, pemilihan rusa betina, persiapan kandang, adaptasi rusa dan pakan, pemberian perlakuan mineral ( $\mathrm{Mg}, \mathrm{Zn}$ dan $\mathrm{Se})$, sinkronisasi birahi dengan spon MPA, pengambilan data lendir serviks meliputi kadar $\mathrm{NaCl}$ dan $\mathrm{pH}$ lendir serviks. Analisis statistik data menggunakan SPSS uji T-Test. Pembuatan mineral sebagai suplementasi diberikan dalam bentuk mineral blok dengan komposisi yang terdiri dari bahan utama dan tambahan. Bahan utama terdiri dari molasses, dedak, onggok dan bungkil kedelai serta bahan tambahan terdiri dari garam, premix, vitamin A D E
$\mathrm{K}$ dan mineral antara lain $\mathrm{Mg}, \mathrm{Zn}$ dan Se. Pembuatan mineral blok dimulai dengan mencampurkan bahan paling sedikit selanjutnya bahan yang lebih banyak, kemudian mengaduk hingga benar-benar homogen. Membentuk mineral blok dari bahan yang sudah dicampur seperti bentuk tabung.

Pelaksanaan sinkronisasi birahi diawali dengan pembuatan spons vagina yang memiliki ketebalan $4 \mathrm{~cm}$. menambahkan MPA yang sudah di encerkan dengan metanol dengan perbandingan $20 \mathrm{mg} / \mathrm{ml}$ pada spons. Mengeringkan selama 48 jam pada box pengering. Melakukan implan spons vagina pada rusa dengan cara sterilisasi aplikator dengan alkohol, mengoleskan KY Jell pada aplikator, sterilisasi vulva, memberikan betadin pada spons, memasukam spons pada aplikator lalu di implankan ke vagina secara hati-hati.

Pemberian obat penenang di-lakukan dengan memberi dosis ACP sebanyak 0.5 $\mathrm{ml}$ dengan cara me-masukankedalam spuit modifikasi, kemudian menambahkan gas korek api agar dapat mendorong cairan masuk kedalam tubuh rusa, menembakkan spuit modifikasi ke rusa sasaran pada bagian paha kaki belakang menggunakan pipa tulup sepanjang 1-2 meter. Obat (ACP) penenang akan bereaksi kurang lebih dalam 30 menit, kemudian menggiring rusa keluar kandang untuk kemudian dilakukan handling dan menutup mata mengg-unakan kain hitam. Bahan mineral blok yang digunakan dapat dilihat pada Tabel 1. 
Tabel 1. Persentasi bahan-bahan penyusun mineral blok

\begin{tabular}{|c|c|c|}
\hline No. & Bahan & Jumlah Presentase \\
\hline & --- & - \\
\hline 1 & Bekatul & 40 \\
\hline 2 & Molases & 35 \\
\hline 3 & Bungkil Kedelai & 10 \\
\hline 4 & Onggok & 6,9 \\
\hline 5 & Garam & 6 \\
\hline 6 & Vitamin ADEK & 0.04699 \\
\hline 7 & \multicolumn{2}{|l|}{ Mineral } \\
\hline & Premix & 2 \\
\hline & $\mathrm{Mg}$ & 0,05 \\
\hline & $\mathrm{Zn}$ & 0,003 \\
\hline & $\mathrm{Se}$ & 0,0001 \\
\hline & Total & 100 \\
\hline
\end{tabular}

Pengambilan lendir dilakukan dalam 8 titik waktu mulai setelah pelepasan implan MPA (asumsi diestrus), selanjutnya 24 jam (asumsi proestrus), 72 jam, 82 jam, 96 jam, 108 jam (asumsi estrus), 120 jam dan 144 jam (asumsi metestrus). Lendir serviks diambil dengan membuka vulva dengan speculum, menyedot lendir serviks dengan kateter kemudian pengukuran $\mathrm{pH}$ dengan $\mathrm{pH}$ indikator dan pengukuran kadar $\mathrm{NaCl}$ lendir serviks dengan mengambil lendir kemudian dicampur aquades sampai $1 \mathrm{ml}$ serta dianalisis uji titrasi kromat dan AgNO3. Kadar $\mathrm{NaCl}$ dari sampel dihitung dengan menggunakan rumus (Rinto et al., 2009).

$$
\frac{(\mathrm{V} 1 . \mathrm{N}) \times \mathrm{B} \times \mathrm{P} \times 100 \%}{\mathrm{~V} 2 \times 1.000}
$$

Keterangan :

$$
\begin{aligned}
& \text { V1 : Volume AgNO3 } \\
& \mathrm{N}: \text { Normalitas AgNO3 } \\
& \mathrm{B}: \mathrm{Mr} \mathrm{NaCl}(58,46) \\
& \mathrm{P}: \text { Faktor pengenceran } \\
& \text { V2 : Volume sampel }
\end{aligned}
$$

\section{HASIL DAN PEMBAHASAN}

\section{Kadar NaCl Lendir Serviks}

Pengamatan kadal $\mathrm{NaCl}$ yang telah dilakukan diperoleh hasil bahwa rata-rata persentase kadar $\mathrm{NaCl}$ lender serviks pada T0 dan T1 rusa Timor berkisar pada 0$0,003 \%$ dari fase ke fase dan dapat dilihat pada Tabel 2. Berdasarkan Tabel 2, setiap individu rusa Timor mempunyai panjang waktu siklus perfase berbeada-beda pada jam ke $(0,24,72,84,96,108,120$ dan 144). Rata-rata menunjukan bahwa kisaran kadar $\mathrm{NaCl}$ lendir serviks setelah pelepasan spon MPA pada fase diestrus T0 dann T1 sama-sama mengalami kenaikan mulai dari fase diestrus, proestrus dan estrus, kemudian turun di fase metestrus. Fase estrus mengalami kenaikan kadar $\mathrm{NaCl}$ paling tinggi dari pada fase-fase lainya, karena saat rusa memasuki fase estrus terjadi peningkatan hormon estrogen. Hormon estrogen mempengaruhi hormon mineralokortikoid, adrenalin dan oksitosin. Mineralokortikoid adalah sub tipe dari golongan hormon kortikoid yang berfungsi 
sebagai regulasi ekskresi cairan elektrolit pada ginjal.

Mineralokortikoid adalah hormon steroid yang bertanggung jawab untuk melestarikan natrium, dan menjaga akan keseimbangan garam natrium, kalium dan hidrogen yang dialirkan ke seluruh tubuh termasuk sel goblet melalui sel-sel saraf.

Tabel 2. Rataan kadar $\mathrm{NaCl}$ dan range lendir serviks Rusa Timor

\begin{tabular}{lccc}
\hline \multirow{2}{*}{ Fase Siklus } & Setelah & \multicolumn{2}{c}{ Perlakuan } \\
\cline { 3 - 4 } & Pelepasan Spon & T0 & T1 \\
\cline { 2 - 4 } & & Rata-Rata & Rata-Rata \\
\cline { 2 - 4 } & ----- Jam ----- & 0,0015 & 0,0019 \\
\hline Diestrus & 0 & 0,0025 & 0,0014 \\
Proestrus & 24 & 0,0028 & 0,0019 \\
Estrus I & 72 & 0,0024 & 0,0027 \\
Estrus II & 84 & 0,0018 & 0,0016 \\
Estrus III & 96 & 0,0015 & 0,0015 \\
Estrus IV & 108 & 0,0014 & 0,0014 \\
Metestrus I & 120 & 0,0015 & 0,0012 \\
Metestrus II & 144 &
\end{tabular}

Mineralokortikoid primer dikenal sebagai aldosteron, dan disekresikan oleh zona glomerulosa (lapisan terluar) dari korteks adrenal. Hormon adrenalin berfungsi meningkatkan tekanan darah, ketika tekanan darah meningkat mengakibatkan aliran darah banyak menuju sel goblet, darah mengakibatkan cairan sitoplasma meningkat dan dibantu oksitosin mempemecahan sitoplasma, sehingga ketika estrus terjadi peningkatan jumlah kadar $\mathrm{NaCl}$ dalam lender meningkat. Hal ini sesuai pendapat Hadley (2000), yang menyatakan bahwa peningkatan estrogen dalam otak pada bagian hipotalamus akan meningkatkan ACTH dan cortices-terone bassaly karena diinduksi oleh hormon luteinizing.

Peningkatan $\mathrm{CRH}$ didalam hipotalmus akan merangsang peng-eluaran adrenocorticotropin (ACTH) di dalam hipofisa. Peningkatan ACTH di dalam hipofisa akan merangsang pembentukan kortisol didalam sel pada zona fasciculata. Zona grome rolusa dan zona fasciculate tidak berbeda jauh ketika terjadi peningkatan ACTH maka zona glomerolus kekurangan 17 -hydroxylase dan akan mensintesis corticosterone dan di ubah menjadi aldosterone. Aldosteron di dalam sel juxtaglomerular (JG) diubah menjadi angiostenin II (AII) melalui biosentitesis angiostenin. Bio-sintesis angiostenin dapat men-yebabkan penyempitan didinding arteri dan menyebabkan tekanan darah meningkat. Ketika tekanan darah meningkat maka atrium jantung akanmenyempit dan mengakibatkan volume darah di jantung berkurang.

Berkurangnya volume darah dijantungdan terjadinya peningkatan tekanan darah menyebabkan terjadinya 
diuresis dan natriuresis. Korteks adrenal memiliki zona glomerulosa yang memproduksi hormon mineralokortikoid kemudian kerja utama hormon ini adalah untuk meningkatkan retensi $\mathrm{Na}^{+}$, ekskresi $\mathrm{K}^{+}$, serta $\mathrm{H}^{+}$, khususnya dalam ginjal dan akan meningkatkan pengeluarandidalam urin. Diperkuat oleh pendapat Babba (2007), yaang menyatakan bahwa peningkatan tekanan darah pada saat vasokontriksi atau pen-yempitan pembuluh darah karena disebabkan perangsangan hormon mengakibabtkan dennyut jantung (pembuluh arteri) semakin cepat. Aliran darah yang cepat meng-akibatkan pengambilan oksigen didalam paru-paru semakin cepat. Denyut jantung yang cepat, berdebar debar dan frekuensi nafas yang naik merupakan bentuk dari stress. Menurut Adinegara (2006), men-yatakan bahwa jumlah lendir terbanyak adalah saat terjadi ovulasi dengan kandungan air, garam organik, protein dan musin.

Fase proestrus dan estrus tersebut termasuk fase folikuler yang dibantu oleh hormone FSH dan LH bertanggung jawab dalam proses folikulogenesis dan ovulasi, sehingga terjadi pertumbuhan dan pematangan folikel. Mineral-mineral lain dalam lendir serviks adalah $\mathrm{K}, \mathrm{Mg}, \mathrm{Ca}, \mathrm{Cu}$ dan $\mathrm{Zn}$ dan dari semuanya $\mathrm{Na}$ terdapat dalam persentase terbesar. Hal ini sesuai pendapat Jainudeen dan Hafez (2000), menyatakan bahwa Follicle stimultaing hormone (FSH) dan luteinizing hormone (LH) bertanggung jawab dalam proses folikulogenesis dan ovulasi, sehingga terjadi per-tumbuhan dan pematangan folikel. Folikel-folikel tersebut akhirnya menghasilkan hormon estrogen yang mampu memanifestasikan gejala birahi. Diperkuat oleh pendapat Mardiati (2003), bahwa lendir serviks meningkat sejalan dengan peningkatan kadar estrogen diikuti dengan peningkatan kadar garam dalam lendir pada saat Puncak ovulasi. Kandungan yang terdapat dalam lendir serviks diantaranya komponen air (95$98,5 \%)$, protein $(1 \%)$, NaCL $(0,8 \%)$ dan musin $(0,5-1,5 \%)$.

Lendir serviks mengandung garamgaram anorganik dengan kadar $1 \%$ dari komponen terlarut dan $\mathrm{NaCl}$ merupakan jenis garam yang terdapat paling banyak yaitu $0,7 \%$. Mineral-mineral lain dalam lendir serviks adalah $\mathrm{K}, \mathrm{Mg}, \mathrm{Ca}, \mathrm{Cu}$ dan $\mathrm{Zn}$ terdapat dalam bentuk trace element yang mempunyai fungsi penting dalah sejumlah enzim dan ribonukleat pada fase luteal dan dari semuanya $\mathrm{Na}$ terdapat dalam persentase terbesar. Menurut Malakar (2014), menyatakan bahwa pada saat puncak birahi terjadi peningkatan hormon estrogen dan salah satu pengaruh yang ditimbulkan dari hormon estrogen adalah terjadi-nya peningkatan kadar $\mathrm{NaCl}$ pada lendir vagina.

Pada Tabel 2, menunjukan bahwa rata-rata nilai kadar $\mathrm{NaCl}$ yang tersaji telah diuji statistik meng-gunakan metode uji Ttest me-nunjukkan bahwa T0 dan T1 tidak berbeda nyata pengaruh pemberian mineral (Mg, Se dan $\mathrm{Zn}$ ) terhadap kadar NaCL lendir serviks selama siklus estrus rusa Timor. Salah satu faktor yang menyebabkan terjadinya hal tersebut adalah kebutuhan mineral (Mg, Se dan $\mathrm{Zn}$ ) sudah terpenuhi dipakan rumput lapang, 
rumput gajah dan singkong. Pada rumput lapang mengandung mineral $\mathrm{Zn}$ tertinggi.

Suplementasi mineral $(\mathrm{Mg}$, Se dan Zn) secara tidak langsung mampu meningkatkan kadar hormon estrogen. Mineral (Mg, Se dan Zn) dapat mempengaruhi sel granulosa dalam memproduksi estrogen dengan cara mengubah androgen menjadi estadiol melalui proses aromatisasi. Ketika estrogen meningkat pada saat fase estrus tampilan birahi akan lebih terlihat. Estrogen merupakan hormon yang berperan dalam menunjukkan tanda-tanda birahi. Peningkatan kadar estrogen menyebabkan aktivitas sel goblet meningkat sehingga cairan plasma menumpuk dan pecah kemudi-an keluarlah lendir serviks. Hormon estrogen mampu meningkatkan sek-resi lendir serviks, sehingga lendir serviks menggantung di vulva atau menempel disekitarnya dan merupa-kan salah satu indikasi ternak sedang birahi.

\section{pH (potential of Hydrogen) Lendir Serviks}

Berdasarkan Tabel 3, setiap individu rusa Timor mempunyai panjang waktu siklus perfase ber-beada-beda pada jam ke $(0,24,72,84,96,108,120$ dan 144). Ratarata menunjukan bahwa kisaran rata-rata pH setelah pelepasan spon MPA pada perlakuan T0 dan $\mathrm{T} 1$ adalah semua $\mathrm{pH}$ cenderung netral dan basa. Pada $\mathrm{pH}$ lendir serviks dipengaruhi oleh kadar estrogenya lebih rendah dibandingkan fase lainnya, karena susunan kimia estrogen yang ada unsur $\mathrm{OH}$ men-yebabkan $\mathrm{pH}$ lendir netral dan cenderung basa dan sperma dapat tetap bertahan hidup lebih lama ketika melewati serviks. Hal tersebut sesuai pendapat dengan Mardiati (2003) menyatakan bahwa lendir yang terletak lebih dekat dengan ostium uteri eksternum $\mathrm{pH}$ menjadi lebih rendah dan lendir yang letaknya lebih dalam memiliki $\mathrm{pH}$ yang lebih tinggi.

Kisaran normal $\mathrm{pH}$ endoserviks pada pertengahan siklus adalah 7-8,5, karena pada saat fase estrus sekresi asam amino meningkat tetapi kon-sentrasinya pada lendir menurun. Sifat tersebut merupakan salah satu faktor untuk membantu spermatozoa untuk tetap hidup lebih lama pada lendir serviks. Menurut pendapat Utomo dan Luh (2012), menyatakan bahwa kadar estrogen dalam darah dipengaruhi oleh kualitas pakan yang diberikan. Pakan dengan kualitas yang baik akan meningkatkan metabolisme tubuh, dan akan mempengaruhi fungsi kelenjar adenohipofisa dalam mensekresikan FSH dan FSH tersebut berfungsi dalam merangsang perkembangan folikel di dalam ovarium yang akan mensekresikan estrogen dengan su-sunan kimia yang mengikat $\mathrm{OH}$ saat birahi sehingga dapat mempengaruhi $\mathrm{pH}$ lendir serviks menjadi netral dan cenderung ke basa. Faktor yang mempengaruhi nilai $\mathrm{pH}$ cenderung netral dan basa, karena sel goblet mempengaruhi enzim lisosim untuk mengurangi bakteri di dalam vagina metabolisme glikogen dan membentuk asam laktat yang bertanggung jawab untuk $\mathrm{pH}$ rendah vagina. Menurut Hussin (2010), bahwa faktor yang menyebabkan $\mathrm{pH}$ lendir bernilai basa adalah sel goblet mempengaruhi enzim lisosim untuk mengurangi bakteri di dalam 
vagina metabolisme glikogen dan membentuk asam laktat yang bertanggung jawab untuk $\mathrm{pH}$ rendah vagina, sehingga ketika asam laktat menurun akan menjadi bersifat basa. Lingkungan vagina bersifat asam memberikan tindakan protektif terhadap mikroorganisme patogen.

Tabel 3. Rata-rata dan range $\mathrm{pH}$ lendir serviks Rusa Timor

\begin{tabular}{lccc}
\hline \multirow{2}{*}{ Fase Siklus } & Setelah & \multicolumn{2}{c}{ Perlakuan } \\
\cline { 3 - 4 } & Pelepasan Spon & T0 & T1 \\
\cline { 3 - 4 } & ---- Jam ---- & Rata-Rata & Rata-Rata \\
\hline Diestrus & 0 & 8,52 & 7,87 \\
Proestrus & 24 & 7,86 & 8,55 \\
Estrus I & 72 & 8,06 & 8,25 \\
Estrus II & 84 & 7,80 & 8,46 \\
Estrus III & 96 & 8,02 & 7,96 \\
Estrus IV & 108 & 8,52 & 7,76 \\
Metestrus I & 120 & 8,70 & 7,73 \\
Metestrus II & 144 & 8,36 & 7,03 \\
\hline
\end{tabular}

Pada Tabel 3, menunjukan bahwa rataan nilai $\mathrm{pH}$ yang tersaji telah diuji statistik menggunakan metode uji T-test menunjukkan bahwa T0 dan T1 tidak berbeda nyata pengaruh pemberian mineral (Mg, Se dan Zn) terhadap $\mathrm{pH}$ lendir serviks selama siklus estrus. Data hasil stasistika uji T-test dapat dilihat pada Lampiran 3.

\section{KESIMPULAN}

Simpulan dari penelitian ini adalah tampilan birahi dapat dilihat dari kadar $\mathrm{NaCl}$ lender serviks pada fase estrus dan $\mathrm{pH}$ netral serta cenderung basa. Tidak ada pengaruh nyata dari suplementasi mineral $(\mathrm{Mg}, \mathrm{Zn}$ dan $\mathrm{Se}$ ) yang berbentuk mineral blok terhadap kadar $\mathrm{NaCl}$ dan $\mathrm{pH}$ lendir serviks selama siklus estrus rusa Timor. Siklus estrus dipengaruhi oleh laju hormon estrogen, adrenalin dan Mineralokortikoid adalah hormon steroid yang bertanggung jawab untuk melestarikan natrium, dan menjaga keseimbangan garam natrium, kalium dan hidrogen akan dialirkan ke seluruh tubuh termasuk sel goblet melalui sel saraf.

\section{UCAPAN TERIMA KASIH}

Ucapan terimakasih kepada Direktorat Penelitian dan Pengabdian kepada masyarakat, Direktorat Jenderal Pendidikan Tinggi Kementrian Riset dan Teknologi Republik Indonesia yang telah mendukung kegiatan penelitian ini melalui dana Penelitian Fundamental 2016, Alam Surya Wijaya. A.Md. yang telah membantu dalam pembuatan spon vagina, kepada Bapak Kelik Isharyudono, S.T. yang telah mendam-pingi pembuatan alat pres dan mineral blok dan Lilik Krismiyanto, S.Pt., M. Si. yang telah membantu uji analisis titrasi kadar $\mathrm{NaCl}$ lendir serviks. 


\section{DAFTAR PUSTAKA}

Adinegara, R. 2006. Penambahan Etinil

Estradiol pada Induksi Ovulasi Menggunakan Klomifen Sitrat.

Tesis. Universitas Diponegoro,

Semarang.

Babba, J. 2007. Hubungan Antara Intensitas Kebisingan di Lingkungan Kerja dengan Peningkat-an Tekanan Darah. Thesis. Universitas Diponegoro, Semarang.

Hadley, M. E. 2000. Endocrinology. $8^{\text {th }}$ Ed. Prentice Hall, United State of America.

Hussin, A. M. 2010. The teory of keratinization. Jour. For Vet. Med. Sci.. 1 (1) : 219-229.

Jainudeen, M. R. and E. S. E. Hafez, 2000. Cattle And Buffalo in Reproduction In Farm Animals. Ed. $7^{\text {th }}$. Edited by
Hafez E. S. E. Lippincott Williams \& Wilkins. Maryland. USA. 159 : 171.

Mardiati, S.M. 2003. Kadar Garam Na Lendir Serviks serta Kadar Garam $\mathrm{Na}$ dan $\mathrm{K}$ Lendir Mulut pada Berbagai Struktur Daun Pakis (Tes ferning). Thesis. Universitas Diponegoro, Semarang.

Samsudewa, D. dan S. S. Capitan. 2011. Reproductive behavior of Timor deer (Rusa timorensis). Jurnal Wartazoa. 21 (3) : 108-113.

Utomo, B. dan L. G. Astiti. 2012. Dampak introduksi teknologi steaming up terhadap estrus post partus sapi perah peranakan Friesian Holstein (PFH). Ed. Retno, S., S. Said, A. Hasan, Ramlanto, Harmoko, L. Kasigit. Pusat Penelitian Bioteknologi LIPI, Bogor. (Prosiding Seminar). 